\title{
Study on Geochemical Characteristics of tight sandstone gas accumulation in Linxing area
}

\author{
Yangbing $\mathrm{Li}^{1}{ }^{1}$, Weiqiang $\mathrm{Hu}^{1}$, Xin $\mathrm{Chen}^{1}$, Litao Ma ${ }^{1}$, Cheng Liu ${ }^{1}$, Duo Wang ${ }^{1}$ \\ ( ${ }^{1}$ CNOOC EnerTech-Drilling \& Production Co., Tianjin 300452, China)
}

\begin{abstract}
Based on the comprehensive analysis of the characteristics of tight sandstone gas composition, carbon isotope, light hydrocarbons and source rocks in Linxing area of Ordos Basin, the reservoir-forming model of tight sandstone gas in this area is discussed. The study shows that methane is the main component of tight sandstone gas, with low contents of heavy hydrocarbons and non-hydrocarbons, mainly belonging to dry gas in the Upper Paleozoic in Linxing area. The values of $\delta 13 \mathrm{C} 1, \delta 13 \mathrm{C} 2$ and $\delta 13 \mathrm{C} 3$ of natural gas are in the ranges of $-45.6 \%$ $\sim-32.9 \%$, $-28.9 \%$ $\sim-22.3 \%$ and $-26.2 \%_{0} \sim-19.1 \%$, respectively. The carbon isotopic values of alkane gas show a general trend of positive carbon sequence. $\delta 13 \mathrm{C} 1$ value is less than $-30 \%$, with typical characteristics of organic genesis. There is a certain similarity in the composition characteristics of light hydrocarbons. The $\mathrm{C} 7$ series show the advantage of methylhexane, while the C5-7 series mainly shows the advantage of isoalkane. The tight sandstone gas in this area is mainly composed of mature coal-derived gas, containing a small amount of coal-derived gas and oil-type gas mixture. According to the mode of hydrocarbon generation, diffusion and migration of source rocks in Linxing area, the tight sandstone gas in the study area can be divided into three types of reservoir-forming assemblages: the upper reservoir type of the far-source type (upper Shihezi formation-shiqianfeng formation sandstone reservoir-forming away from source rocks), the upper reservoir type of the near-source type ( the Lower Shihezi formation sandstone reservoir-outside the source rock), and the self-storage type of the source type (Shanxi formation-Taiyuan formation source rock internal sand reservoir).
\end{abstract}

\section{Introduction}

With the continuous breakthroughs and development of exploration and development technologies, unconventional oil and gas has become a replacement energy source for the stable crude oil production and the rapid growth of natural gas production in China ${ }^{[1-4]}$. From the perspective of national energy development strategy, entering the field of unconventional oil and gas is an important development strategy of the "13th Five-Year Plan". CNPC, Sinopec and CNOOC are all committed to the rapid development of unconventional oil and gas industries, and have successively established national demonstration projects for tight gas, shale gas and coalbed methane. The Ordos Basin is the second largest petroliferous basin on land in China. Generally, it is a large, asymmetric, north-south, superimposed craton basin with a steep and narrow west flank and a wide east flank ${ }^{[5-6]}$, which contains very rich unconventional oil and gas resources $^{[7-8]}$. After more than 50 years of exploration and development research, the Sulige, Daniudi, Yulin, Zizhou, Mizhi, Shenmu, Wushenqi, Dongsheng and other large tight sandstone gas fields have been discovered in the basin, which are hundreds of billions of cubic meters currently discovered in China. The basin with the most large gas fields above the meter level shows that this area has huge natural gas exploration potential ${ }^{[9-11]}$.

Linxing area is located in the eastern margin of the Ordos Basin, rich in oil and gas resources. Drilling gas loggings in this area show that gas is generally contained in the 5th section of Shiqianfeng Formation (Qian5).Taiyuan Formation (P1t), and the thickness of single well drilling gas layer is mainly distributed between 20 and $80 \mathrm{~m}$, with an average thickness of $34.6 \mathrm{~m}$; The layers are mainly concentrated in the Qian5 Member, upper Shihezi Formation (He 4 Member) Lower Shihezi Formation (He 8 Member), and Taiyuan Formation. The fracturing test shows that some exploration wells have obtained industrial airflow or low-yield airflow, indicating that the study area has good prospects for exploration ${ }^{[12-}$ ${ }^{13]}$. Due to the relatively low degree of exploration and development of tight sandstone gas in Linxing area, there is no systematic understanding of the tight sandstone gas accumulation model in this area. Especially in the Early Cretaceous, the intrusion of the Zijinshan intrusions in the middle east resulted in the formation of the Zijinshan uplift ${ }^{[14-15]}$. The effect of the formation of uplift on the migration and accumulation of natural gas is not clear, the

${ }^{{ }^{*} \text { Corresponding author: liyb2@cnooc.com.cn }}$ 
depth of research restricted and understanding. Therefore, it is necessary to strengthen the analysis and research on the tight sandstone gas accumulation model in Linxing area to provide guidance for the exploration and development of tight gas reservoirs in this area.

\section{Geological background}

The Linxing area (Figure 1) is mainly located in Linxian and Xingxian on the eastern margin of the Ordos Basin. It is mainly located in the flexure belt in the west of Shanxi. The whole presents the trend of east high and west low [16-18]. According to the comparative observation of field outcrops and the drilling of exploration wells, the Carboniferous-Permian in the study area developed from bottom to top with Benxi Formation (C2b)-Taiyuan Formation (P1t)-Shanxi Formation (P1s)-Shihezi Formation (P2h) -Shi Qianfeng Group (P3sq). Among them, C2b-P1t-P1s mainly developed mudstone and coal as gas source rocks; P2h-Qian5 formation mainly developed sand and mudstone interbeds. At the same time, the thick mudstone of Shiqianfeng Formation can be used as a regional caprock for gas reservoirs and seal Natural gas migrates upwards and forms multiple sets of reservoircap combination relationships with underlying reservoirs. Based on core observations, the author used the gas composition, carbon isotopes, light hydrocarbons of 17 wells in Linxing area, and source rock organic carbon, rock pyrolysis, vitrinite reflectivity and other large amounts of geochemistry in the Linxing area. Test data, comprehensively analyze and study the geochemical characteristics, genetic types, gas sources, and hydrocarbon generation potential of the Upper Paleozoic natural gas in the study area, determine the origin and source of tight gas, and clarify the accumulation mode of tight sandstone gas. Provide directional guidance for the expansion of subsequent exploration fields.

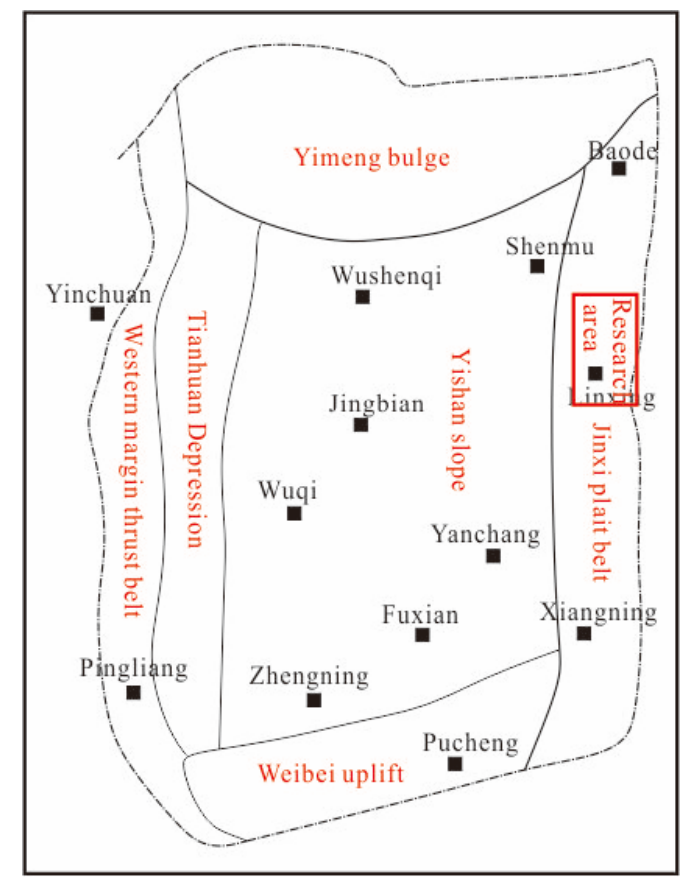

Fig.1. Comprehensive schematic diagram in the study area

\section{Sample collection and test analysis methods}

In this paper, 17 gas samples from 17 wells in Linxing area were collected for analysis of natural gas composition, carbon isotope and light hydrocarbons; more than 200 samples of mudstone and coal from 35 wells were analyzed for rock pyrolysis, organic carbon content determination, and mirror analysis. The above tests are all done by the Unconventional Experiment Center of CNOOC Energy Development Co., Ltd. Engineering Technology Branch. Among them, natural gas component analysis uses Agilent 7890B gas chromatograph, carbon isotope analysis uses Elementar isoprime vision isotope analyzer, light hydrocarbon uses Agilent 6890A gas chromatograph, rock pyrolysis analysis uses Rock-Eval 6 pyrolysis analyzer, organic carbon content The CS-744 carbon-sulfur analyzer was used for the determination, and the CRAIC 508PV vitrinite reflectance meter was used for the measurement of vitrinite reflectance. The test results of natural gas components, carbon isotopes and light hydrocarbons are shown in Table 1 and Table 2; the statistical results of rock pyrolysis, organic carbon determination and vitrinite reflectance determination of mudstone and coal are shown in Table 3 below.

\section{Results and discussion}

\subsection{Geochemical characteristics of natural gas}

\subsubsection{Characteristics of composition}

The test results of tight sandstone gas components in Linxing area (Table 1) show that the content of $\mathrm{CH} 4$ ranges from $90.74 \% \sim 99.32 \%$, with an average value of $95.29 \%$; the content of $\mathrm{C} 2 \mathrm{H} 6$ ranges from $0.12 \% \sim 6.31 \%$, with an average value of $2.04 \%$; the content of $\mathrm{C} 3 \mathrm{H} 8$ ranges from $0 \sim 1.68 \%$, the average value is $0.42 \%$; the drying coefficient is between 0.924 and 0.998 , and the average value is 0.973 . Only 3 of the 17 gas samples are wet, and the rest are dry gas. The non-hydrocarbon gases are mainly $\mathrm{CO} 2$ and $\mathrm{N} 2$. Among them, the carbon dioxide content ranges from $0 \sim 2.1 \%$, with an average value of $0.38 \%$; the nitrogen content ranges from $0 \sim 6.47$, with an average value of $1.56 \%$. 
Table 1. Gas composition and carbon Isotope of tight sandstone in Linxing area

\begin{tabular}{|c|c|c|c|c|c|c|c|c|c|c|c|}
\hline \multirow[t]{2}{*}{ number } & \multirow{2}{*}{ position } & \multicolumn{7}{|c|}{ constituent content $\quad(\%)$} & \multirow{2}{*}{$\begin{array}{c}\text { aridity } \\
\text { coefficient }\end{array}$} & $\delta^{13} \mathrm{C}(\%, \quad \mathrm{VPDB})$ & \multirow[t]{2}{*}{$\begin{array}{l}\mathrm{Ro}^{(1)} \\
(\%)\end{array}$} \\
\hline & & $\mathrm{CH}_{4}$ & $\mathrm{C}_{2} \mathrm{H}_{6}$ & $\mathrm{C}_{3} \mathrm{H}_{8}$ & $\mathrm{iC}_{4} \mathrm{H}_{10}$ & $\mathrm{nC}_{4} \mathrm{H}_{10}$ & $\mathrm{CO}_{2}$ & $\mathrm{~N}_{2}$ & & $\mathrm{C}_{2}$ & \\
\hline 1 & $\mathrm{P}_{2} \mathrm{sq}$ & 99.32 & 0.21 & 0.00 & 0.00 & 0.00 & 0.40 & 0.00 & 0.998 & l & l \\
\hline 2 & $\mathrm{P}_{2} \mathrm{~h}$ & 93.06 & 0.98 & 0.21 & 0.04 & 0.05 & 0.04 & 5.54 & 0.986 & $-37.7-25.5-23.5$ & 0.58 \\
\hline 3 & $\mathrm{P}_{2} \mathrm{~h}$ & 97.96 & 1.56 & 0.28 & 0.05 & 0.05 & 0.00 & 0.11 & 0.981 & $-36-26.1-23.5$ & 0.77 \\
\hline 4 & $\mathrm{P}_{2} \mathrm{~h}$ & 96.82 & 1.35 & 0.36 & 0.06 & 0.07 & 0.02 & 1.2 & 0.981 & $-37.3-27.2-24.8$ & 0.62 \\
\hline 5 & $\mathrm{P}_{2} \mathrm{~h}$ & 97.14 & 1.17 & 0.20 & 0.04 & 0.03 & 0.03 & 1.32 & 0.985 & $\begin{array}{lll}-37.5 & -27.1 & -24.0\end{array}$ & 0.6 \\
\hline 6 & $\mathrm{P}_{2} \mathrm{~h}$ & 91.16 & 4.69 & 1.33 & 0.19 & 0.26 & 0.02 & 1.94 & 0.934 & $-34.8-27.5-25.3$ & 0.94 \\
\hline 7 & $\mathrm{P}_{2} \mathrm{~h}$ & 93.93 & 2.73 & 0.76 & 0.13 & 0.19 & 0.04 & 1.76 & 0.961 & $-36.4-26.6-24.7$ & 0.72 \\
\hline 8 & $\mathrm{P}_{2} \mathrm{~h}$ & 93.82 & 1.15 & 0.32 & 0.06 & 0.09 & 0.01 & 3.78 & 0.983 & $-36.5-28.9-26.0$ & 0.71 \\
\hline 9 & $\mathrm{P}_{2} \mathrm{~h}$ & 98.92 & 0.84 & 0.13 & 0.00 & 0.00 & 0.11 & 0.00 & 0.990 & $\begin{array}{lll}-32.9 & -23.9 & -21.6\end{array}$ & 1.28 \\
\hline 10 & $\mathrm{P}_{2} \mathrm{~h}$ & 98.00 & 1.44 & 0.28 & 0.05 & 0.05 & 0.06 & 0.11 & 0.982 & $\begin{array}{lll}-37.2 & -26.1 & -24.1\end{array}$ & 0.63 \\
\hline 11 & $\mathrm{P}_{2} \mathrm{~h}$ & 94.56 & 3.60 & 0.90 & 0.14 & 0.15 & 0.08 & 0.49 & 0.952 & $-34.6-25.9-24.5$ & 0.97 \\
\hline 12 & $\mathrm{P}_{1} \mathrm{~S}$ & 90.74 & 5.20 & 1.68 & 0.23 & 0.32 & 0.05 & 1.45 & 0.924 & $\begin{array}{lll}-33.2 & -28.1 & -26.2\end{array}$ & 1.21 \\
\hline 13 & $\mathrm{P}_{1} \mathrm{t}$ & 96.04 & 0.75 & 0.08 & 0.02 & 0.02 & 2.1 & 0.97 & 0.991 & $\begin{array}{lll}-39.8 & -24.1 & -20.3\end{array}$ & 0.41 \\
\hline 14 & $\mathrm{P}_{1} \mathrm{t}$ & 92.68 & 6.31 & 0.28 & 0.13 & 0.12 & 0.15 & 0.45 & 0.931 & $-41.3-22.3$ & 0.32 \\
\hline 15 & $\mathrm{P}_{1} \mathrm{t}$ & 93.33 & 0.12 & 0.00 & 0.00 & 0.00 & 0.02 & 6.47 & 0.990 & $-40.4-26.5-19.1$ & 0.38 \\
\hline 16 & $\mathrm{P}_{1} \mathrm{t}$ & 96.53 & 1.14 & 0.17 & 0.03 & 0.03 & 1.8 & 0.25 & 0.986 & $\begin{array}{lll}-41.1 & -24.8 & -22.8\end{array}$ & 0.33 \\
\hline 17 & $\mathrm{P}_{1} \mathrm{t}$ & 95.93 & 1.48 & 0.23 & 0.04 & 0.04 & 1.58 & 0.62 & 0.982 & $-39.6-24.6-22.7$ & 0.43 \\
\hline
\end{tabular}

Note: The formula for calculating the Ro ${ }^{(1)}$ value of natural gas comes from Dai Jinxing ${ }^{[19]} \quad(1993): \delta^{13} \mathrm{C}_{1}=14.12 \operatorname{lgRo}-34.39$.

\subsubsection{Characteristics of carbon isotope}

The carbon isotope test results of tight sandstone gas in Linxing area (Table 1) show that the $\delta 13 \mathrm{C} 1$ value is distributed from $-41.3 \sim-32.9 \%$, with an average value of $-37.1 \%$; the $813 \mathrm{C} 2$ value is distributed from $-28.9 \%$ $20.9 \%$, with an average value of $-25.7 \%$; $\delta 13 \mathrm{C} 3$ values are distributed from $-26.2 \% \sim-19.1 \%$, with an average value of $-23.5 \%$. The $\delta 13 \mathrm{C} 1$ value is lighter than the $\delta 13 \mathrm{C} 2$ and $\delta 13 \mathrm{C} 3$ values. The carbon isotope values of natural gas in the study area show a positive carbon sequence change $(\delta 13 \mathrm{C} 1<\delta 13 \mathrm{C} 2<\delta 13 \mathrm{C} 3$ ) (Table 1 ), and the $\delta 13 \mathrm{C} 1$ values are all less than $-30 \%$, which has typical characteristics of organic gas.

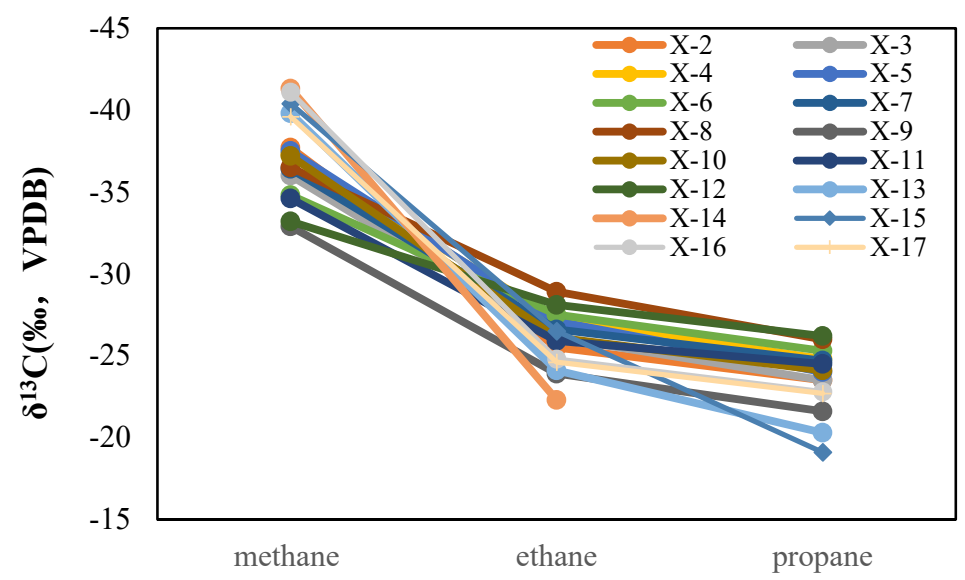

Fig. 2. The characteristics of carbon isotopic distribution of natural gas monomers in Linxing area

\subsubsection{Characteristics of light hydrocarbons}

The light hydrocarbon parameters of tight sandstone gas in Linxing area (Table 2) show that the methylcyclohexane index $(\mathrm{MCH})$ of the $\mathrm{C}_{7}$ series ranges from $52.7 \%$ to $69.6 \%$, all greater than $50 \%$, with an average value of $61.9 \%$; Dimethylcyclopentane ( $\Sigma$ DMCP) is distributed in 
13.9 21.9\%, with an average value of $18.7 \%$; n-heptane $\left(\mathrm{nC}_{7}\right)$ is distributed in 12.1 29.1\%, all less than $35 \%$, with an average value of $19.4 \% ; \mathrm{C}_{5-7}$ series of n-alkanes are mainly distributed in $13.2 \% \sim 35.7 \%$, with an average of $23.2 \%$; $\mathrm{C}_{5-7}$ alkanes in various configurations are mainly distributed in $26.8 \sim 56.5 \%$, with an average of $45.4 \%$; and cycloalkanes are mainly distributed in $12.6 \sim 58.8 \%$, with an average of $31.3 \%$. Comprehensive research suggests that the light hydrocarbon composition of natural gas in the study area is similar, the $\mathrm{C}_{7}$ series show the advantage of methylcyclohexane, and the main body of the $\mathrm{C}_{5-7}$ series show the advantage of isoparaffins.

Table 2. The Light hydrocarbon parameters of tight sandstone gas in Linxing area

\begin{tabular}{|c|c|c|c|c|c|c|c|}
\hline number & position & $\mathrm{nC}_{7} / \%$ & $\mathrm{MCH} / \%$ & $\sum \mathrm{DMCC} 5 / \%$ & $\begin{array}{c}\mathrm{C}_{5-7} \mathrm{~N}- \\
\text { alkanes } / \%\end{array}$ & $\begin{array}{c}\mathrm{C}_{5-7} \\
\text { isoparaffin } \\
/ \%\end{array}$ & $\begin{array}{c}\mathrm{C}_{5-7} \\
\text { cycloalkanes } \\
/ \%\end{array}$ \\
\hline 1 & $\mathrm{P}_{2} \mathrm{~h}$ & 12.4 & 65.8 & 21.9 & 18.5 & 55.4 & 26.1 \\
\hline 2 & $\mathrm{P}_{2} \mathrm{~h}$ & 24.5 & 58.2 & 17.3 & 30.9 & 56.5 & 12.6 \\
\hline 3 & $\mathrm{P}_{2} \mathrm{~h}$ & 14.9 & 66.7 & 18.5 & 15.3 & 47.0 & 37.7 \\
\hline 4 & $\mathrm{P}_{2} \mathrm{~h}$ & 14.5 & 65.7 & 19.8 & 25.6 & 52.0 & 22.4 \\
\hline 5 & $\mathrm{P}_{2} \mathrm{~h}$ & 26.8 & 53.5 & 19.7 & 30.6 & 46.5 & 22.9 \\
\hline 6 & $\mathrm{P}_{2} \mathrm{~h}$ & 26.6 & 52.7 & 20.8 & 14.4 & 26.8 & 58.8 \\
\hline 7 & $\mathrm{P}_{2} \mathrm{~h}$ & 29.1 & 57.0 & 13.9 & 35.9 & 43.9 & 20.2 \\
\hline 8 & $\mathrm{P}_{1} \mathrm{~S}$ & 22.6 & 60.6 & 16.8 & 33.0 & 52.3 & 14.7 \\
\hline 9 & $P_{1} t$ & 14.4 & 63.7 & 21.9 & 13.2 & 34.2 & 52.5 \\
\hline 10 & $P_{1} t$ & 12.1 & 69.6 & 18.3 & 20.2 & 44.8 & 35.0 \\
\hline 11 & $P_{1} t$ & 15.2 & 67.8 & 17.0 & 18.2 & 39.7 & 42.1 \\
\hline
\end{tabular}

\subsection{Gas Formation and Source Analysis of Compact Sandstone}

\subsubsection{Gas Factor Analysis of Compact Sandstone}

\subsubsection{Carbon isotope identification}

The carbon isotope sequences of methane and ethane and their homologs are important indicators to determine the origin of natural gas, and are usually used to identify the origin of natural gas. The carbon isotope composition of alkane gas of organic origin gas has a positive carbon sequence $(\delta 13 \mathrm{C} 1<\delta 13 \mathrm{C} 2<\delta 13 \mathrm{C} 3<\delta 13 \mathrm{C} 4)$. The carbon isotope value of methane is generally less than $-30 \%$, while the inorganic origin gas is the opposite. Different scholars use $\delta 13 \mathrm{C} 2$ to distinguish between coal-derived gas and oil-type gas, but the overall difference is not big. Referring to the previous division of coal-derived gas and oil-type gas by using $\delta 13 \mathrm{C} 2$, this paper uses $\delta 13 \mathrm{C} 2$ value greater than $-28 \%$ and $\delta 13 \mathrm{C} 3$ value greater than $-25 \%$ to identify natural gas as coal-derived gas; $\delta 13 \mathrm{C} 2$ value is between $-30 \%$ - 28 If between $\%$, it is recognized as a mixture of coal-derived gas and oil-type gas; if the $\delta 13 \mathrm{C} 2$ value is less than $-30 \%$, it is recognized as oil-type gas. The carbon isotope values of tight sandstone gas in Linxing area show a positive carbon sequence $(\delta 13 \mathrm{C} 1<\delta 13 \mathrm{C} 2<\delta 13 \mathrm{C} 3)$ (Table 1, Figure 2), and the $\delta 13 \mathrm{C} 1$ values are all less than $-30 \%$, which is of organic origin; $\delta 13 \mathrm{C} 2$ values are distributed in $-28.9 \% \sim-22.3 \%$, the $\delta 13 \mathrm{C} 3$ value is distributed from $-26.2 \%$ to $-19.1 \%$, only 2 of the 16 samples the $\delta 13 \mathrm{C} 2$ value less than $-28 \%$ and $\delta 13 \mathrm{C} 3$ value less than $-25 \%$. The sample points are mainly distributed in the coal-derived gas interval. It belongs to coal-derived gas, with only a few sample points scattered in the mixed gas interval, which is a mixture of coal-derived gas and oil-type gas (Figure 3 and Figure 4) 


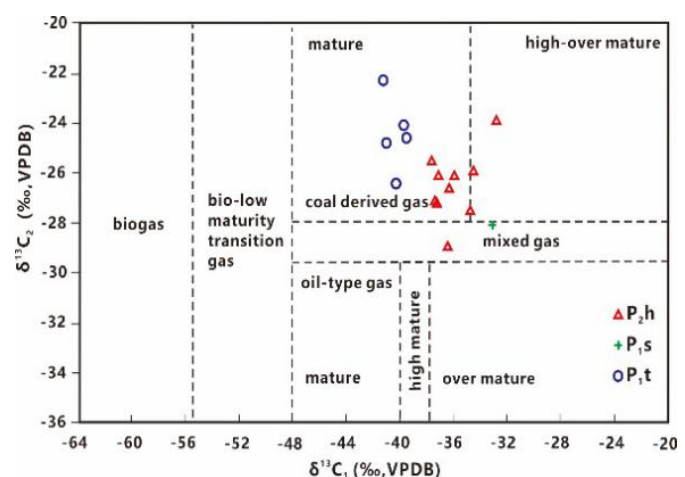

Fig.3. The identification of genetic types of natural gas $\delta^{13} \mathrm{C}_{2}-\delta^{13} \mathrm{C}_{1}$ (Sun Pingan et al., 2012)

\subsubsection{Causes of light hydrocarbon identification}

According to previous research results [21-24], the relative content of dimethylcyclopentane ( $\Sigma \mathrm{DMCP})$, nheptane (nC7) and methylcyclohexane (MCH) in the $\mathrm{C} 7$ series of light hydrocarbons, And the relative content of cycloalkanes, n-alkanes and isoalkanes in the C5-7 series to distinguish the types of organic matter. According to the light hydrocarbon test results of the gas samples (Table 2) and the light hydrocarbon distribution triangle map (Figure 5, Figure 6), the analysis shows that the relative content of n-heptane $(\mathrm{nC} 7)$ in the light hydrocarbon $\mathrm{C} 7$ series of tight sandstone gas in the study area is between

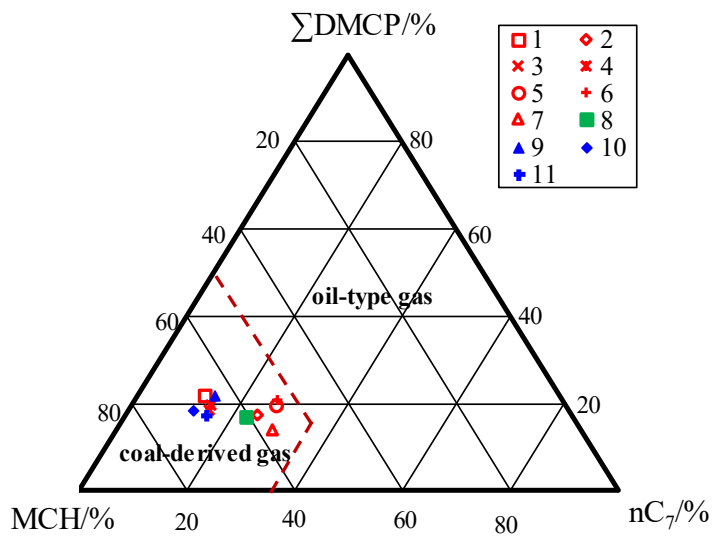

Fig. 5. The ternary diagram of $\mathrm{C}_{7}$ light hydrocarbon series distribution of natural gas

\subsubsection{Gas source analysis of tight sandstone}

The source rock of the Upper Paleozoic in Linxing area is mainly coal, followed by dark mudstone. Among them, the thickness of coal mainly ranges from 12 to $22 \mathrm{~m}$, with an average value of $16 \mathrm{~m}$; the thickness of dark mudstone mainly ranges from 95 to $115 \mathrm{~m}$, with an average value of $103 \mathrm{~m}$ [25]. The test results of coal and dark mudstone in the study area (Table 3) show that the abundance of organic matter is high and belongs to medium-good source

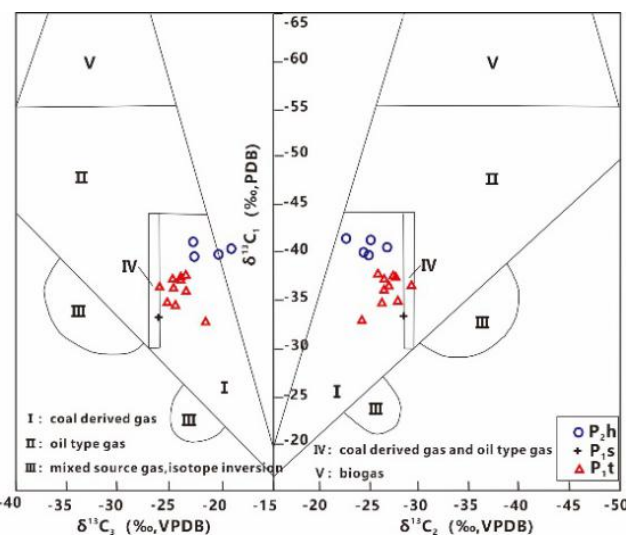

Fig. 4. The identification of genetic types of natural gas $\delta^{13} \mathrm{C}_{1}-\delta^{13} \mathrm{C}_{2}-\delta^{13} \mathrm{C}_{3}$ (Dai Jinxing et al., 2012)

12.1 and $29.1 \%$, both are less than $35 \%$; the relative content of methylcyclohexane (MCH) is between $52.7 \%$ and $69.6 \%$, both greater than $50 \%$, and the samples fall within the range of coal-derived gas, which belongs to coal-derived gas. The relative content of C5 -7 n-alkanes in the C5-7 series is between $13.2 \% \sim 35.7 \%$. Among the 11 light hydrocarbon samples, the relative content of C5 $7 \mathrm{n}$-alkanes is less than $30 \%$, and most of them The sample points fall within the coal-derived gas range, and only a small part of the samples fall within the oil-type gas range. That is, the Upper Paleozoic natural gas in the study area is mainly coal-derived gas and contains a small amount of oil-type mixed gas. This is the same as the previous carbon isotope analysis research The results are consistent.

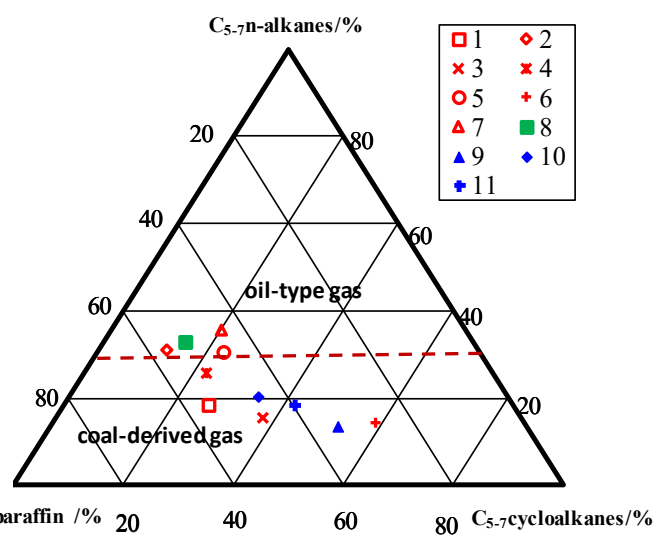

Fig. 6. The ternary diagram of $\mathrm{C}_{5-7}$ light hydrocarbon series distribution of natural gas

rock; the type of organic matter belongs to type III, mainly gas generation; Ro value is mainly between $0.8 \%$ and $1.5 \%$. At the stage of maturity-higher than the maturity stage, entering the stage of massive vitality. Due to the intrusion of the Zijinshan pluton in the east and middle of the study area, the reflectance value of the area around Zijinshan is greater than $2.0 \%$, even reaching $4.2 \%$, which is in the over-mature stage; the gas generation intensity is mainly between $(18 \sim 32) \times 108 \mathrm{~m} 3 / \mathrm{km} 2$.It laid a rich material foundation for the accumulation of tight 
sandstone gas in the later stage.

Table 3. The Geochemical parameters of Source Rocks in Linxing area

\begin{tabular}{|c|c|c|c|c|c|}
\hline & genre & organic carbon $(\%)$ & $\mathrm{S}_{1}+\mathrm{S}_{2}(\mathrm{mg} / \mathrm{g})$ & Ro $(\%)$ & $\operatorname{Tmax}\left({ }^{\circ} \mathrm{C}\right)$ \\
\hline \multirow{5}{*}{$\mathrm{P}_{1 \mathrm{~S}}$} & \multirow{2}{*}{ coal } & $\underline{58.50 \sim 74.00}$ & 51.57 167.84 & $\underline{0.98 \sim 1.13}$ & $\underline{458.0 \sim 463.0}$ \\
\hline & & $63.82(5)$ & $102.91(5)$ & $1.07(5)$ & $461.0(7)$ \\
\hline & \multirow{3}{*}{ Dark mudstone } & & & & \\
\hline & & $\underline{0.75 \sim 21.80}$ & $\underline{0.54 \sim 71.10}$ & $\underline{0.78 \sim 1.38}$ & $\underline{426.0 \sim 480.0}$ \\
\hline & & $3.28(49)$ & $5.03(37)$ & $0.98(31)$ & $461.0(35)$ \\
\hline \multirow{4}{*}{$\mathrm{P}_{1} \mathrm{t}$} & \multirow{2}{*}{ coal } & $\underline{45.60 \sim 76.10}$ & $\underline{45.33 \sim 309.37}$ & $\underline{0.87 \sim 1.45}$ & $\underline{447.0 \sim 501.0}$ \\
\hline & & $63.28(16)$ & $158.53(13)$ & $1.18(9)$ & $463.2(23)$ \\
\hline & \multirow{2}{*}{ Dark mudstone } & $\underline{0.82 \sim 19.20}$ & $\underline{0.53 \sim 8.81}$ & $\underline{0.81 \sim 1.42}$ & $\underline{442.0 \sim 510.0}$ \\
\hline & & $4.16(22)$ & $2.80(17)$ & $1.07(24)$ & $470.3(20)$ \\
\hline \multirow{4}{*}{$\mathrm{C}_{2} \mathrm{~b}$} & \multirow{2}{*}{ coal } & $\underline{39.60 \sim 84.60}$ & $\underline{38.67 \sim 250.00}$ & $\underline{0.93 \sim 1.48}$ & $\underline{454.0 \sim 517.0}$ \\
\hline & & $64.03(14)$ & $118.18(10)$ & $1.21(8)$ & $485.3(15)$ \\
\hline & \multirow{2}{*}{ Dark mudstone } & $0.78 \sim 12.00$ & $0.58 \sim 17.93$ & $0.89 \sim 1.39$ & $450.0 \sim 508.0$ \\
\hline & & $3.66(30)$ & $3.12(25)$ & $1.12(29)$ & $482.7(30)$ \\
\hline
\end{tabular}

Note: Minimum $\sim$ maximum

Average (number of samples)

The $\delta^{13} \mathrm{C}_{1}$ of natural gas has a good linear relationship with Ro value, which can be used as an effective method for gas source comparison. According to the empirical formula of coal-derived gas established by Dai Jinxing (1993): $\delta^{13} C_{1}=14.12 \operatorname{lgRo}-34.39$, the natural gas maturity of the study area is calculated. The calculation results (Table 1) show that the Ro value of $P_{1} t$ natural gas in the study area is mainly between $0.32 \% \sim 0.43 \%$, and the average value is $0.38 \%$, which is significantly lower than the measured Ro value of coal and dark mudstone; the Ro value of $\mathrm{P}_{2} \mathrm{~h}$ natural gas is mainly between $0.58 \% \sim 1.28 \%$, with an average value of $0.82 \%$, which is lower than the measured Ro value of $P_{1} t$ and P1s source rock maturity. Since the $\mathrm{P}_{1} \mathrm{t}-\mathrm{P} 1 \mathrm{~s}$ in the study area belong to the transitional coal-measure strata of the land and sea, the $\mathrm{P}_{1} \mathrm{~s}-\mathrm{P}_{1} \mathrm{t}$ strata are mainly in the brackish water-salt water sedimentary environment, and the water medium is the key to the natural gas $\delta^{13} \mathrm{C}_{1}$. The saltier the water medium, the lower the $\delta^{13} \mathrm{C}_{1}$ value of natural gas, resulting in the calculated $\mathrm{P}_{1} \mathrm{~s}$ and $\mathrm{P}_{1} t$ natural gas maturity lower than the measured Ro. Overall, the $\mathrm{P}_{1} \mathrm{t}$ tight sandstone gas comes from its own source rock of the Taiyuan Formation, and the $\mathrm{P}_{2} \mathrm{~h}$ tight sandstone gas mainly comes from the $\mathrm{P}_{1} \mathrm{~s}$ source rock in addition to the $\mathrm{P}_{1} \mathrm{t}$ source rock.

\subsection{Gas reservoir model of tight sandstone}

Prinzhofer et al. (1995) ${ }^{[26]}$ and Prinzhofer and Pernaton (1997) ${ }^{[27]}$ have shown that the distribution of natural gas $\ln \left(\mathrm{C}_{1} / \mathrm{C}_{2}\right)-\left(\delta^{13} \mathrm{C}_{1}-\delta^{13} \mathrm{C}_{2}\right)$ and $\delta^{13} \mathrm{C}_{1}-(\mathrm{C} 2 / \mathrm{C} 1)$ can be comprehensively reflected The thermal evolution and secondary transformation process experienced by natural gas (mainly the process of migration and accumulation). When natural gas has not undergone the secondary reformation process or the secondary reformation process is weak, the difference in composition and carbon isotope composition is mainly controlled by the maturity of the source rock, and the $\ln \left(\mathrm{C}_{1} / \mathrm{C}_{2}\right)$ and $\delta^{13} \mathrm{C}_{1}-\delta^{13} \mathrm{C}_{2}$ parameters all follow the source rock As the maturity increases, the $\delta^{13} \mathrm{C}_{1}$ and $\mathrm{C}_{2} / \mathrm{C}_{1}$ parameters both decrease as the source rock maturity increases. When natural gas is subjected to diffusion, migration and loss, it is manifested as $\ln \left(\mathrm{C}_{1} / \mathrm{C}_{2}\right)$ decreases, and the difference between $\delta^{13} \mathrm{C}_{1}-\delta^{13} \mathrm{C}_{2}$ gradually increases; $\delta^{13} \mathrm{C}_{1}$ decreases, and the $\mathrm{C}_{2} / \mathrm{C}_{1}$ ratio gradually decreases. The $\delta^{13} \mathrm{C}_{1}-\delta^{13} \mathrm{C}_{2}$ difference of $\mathrm{P} 1 \mathrm{t}$ tight sandstone gas in Linxing area increases simultaneously with $\ln \left(\mathrm{C}_{1} / \mathrm{C}_{2}\right)$, and the ratio of $\delta^{13} \mathrm{C}_{1}$ to $\mathrm{C}_{2} / \mathrm{C}_{1}$ decreases simultaneously, reflecting the trend of $\mathrm{P} 1 \mathrm{t}$ tight gas change with maturity; $\mathrm{P} 2 \mathrm{~h}$ tight gas reservoir The difference between $\delta^{13} \mathrm{C}_{1}-\delta^{13} \mathrm{C}_{2}$ of natural gas in natural gas gradually increases, $\ln \left(\mathrm{C}_{1} / \mathrm{C}_{2}\right)$ gradually decreases, and the ratio of $\delta^{13} \mathrm{C}_{1}$ to $\mathrm{C}_{2} / \mathrm{C}_{1}$ increases simultaneously, indicating that the $\mathrm{P}_{2} \mathrm{~h}$ tight sandstone gas has obvious characteristics of diffusion and migration (Figure 7, Figure 8) . Comprehensive analysis suggests that the $P_{2}$ h tight sandstone gas reservoir in the study area is mainly from the $\mathrm{P}_{1} \mathrm{~s}$ source rock hydrocarbon generation, pressurized diffusion and migration to near-source or far-source reservoirs to charge and accumulate; the $P_{1}$ t tight sandstone gas reservoir mainly comes from $\mathrm{P}_{1} \mathrm{t}^{\prime} \mathrm{s}$ own hydrocarbon source Rock, self-generating and self-storing in the source rock. 


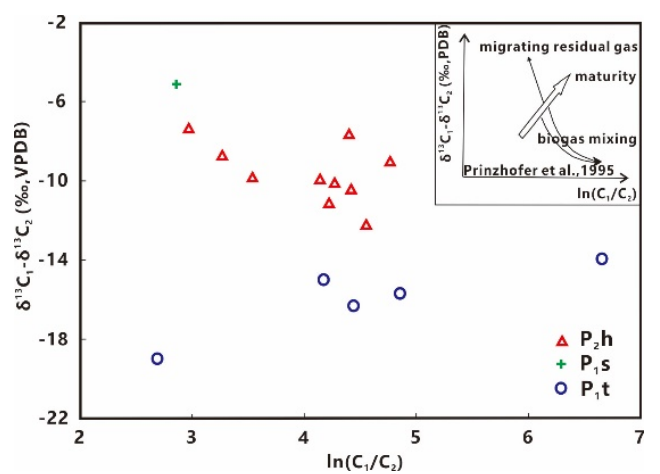

Fig.7. The relationship diagram of tight sandstone gas $\operatorname{Ln}\left(\mathrm{C}_{1} / \mathrm{C}_{2}\right)-\left(\delta^{13} \mathrm{C}_{1}-\delta^{13} \mathrm{C}_{2}\right)$ in Linxing area

Based on the above analysis of the origin and source of tight sandstone gas in the Linxing area, it is concluded that the tight sandstone gas in the study area can be divided into three accumulation modes (Figure 9): remote source type, lower generation and upper storage type (far away from the source rock) Upper Shihezi Formation-

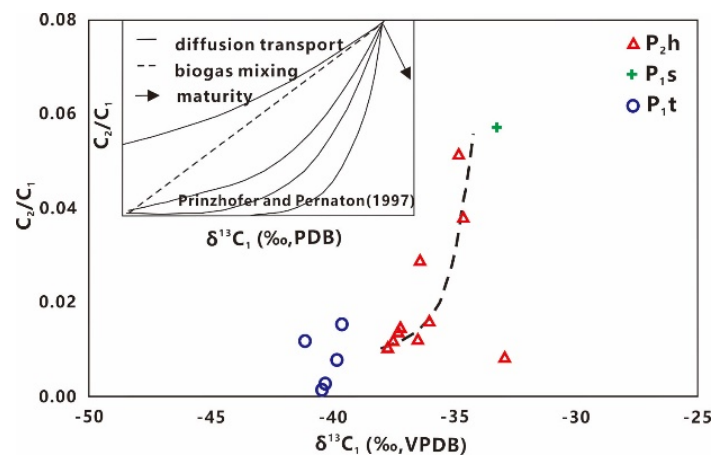

Fig.8. The relationship diagram of tight sandstone gas $\delta^{13} \mathrm{C}_{1}-\left(\mathrm{C}_{2} / \mathrm{C}_{1}\right)$ in Linxing area

Shiqianfeng Formation Sandbody Accumulation); Nearsource type lower generation and upper storage type (lower Shihezi Formation sand body accumulation outside the source rock); In-source type self-generation and selfstorage type (Shanxi Formation-Taiyuan Formation source rock Accumulation of internal sand bodies).

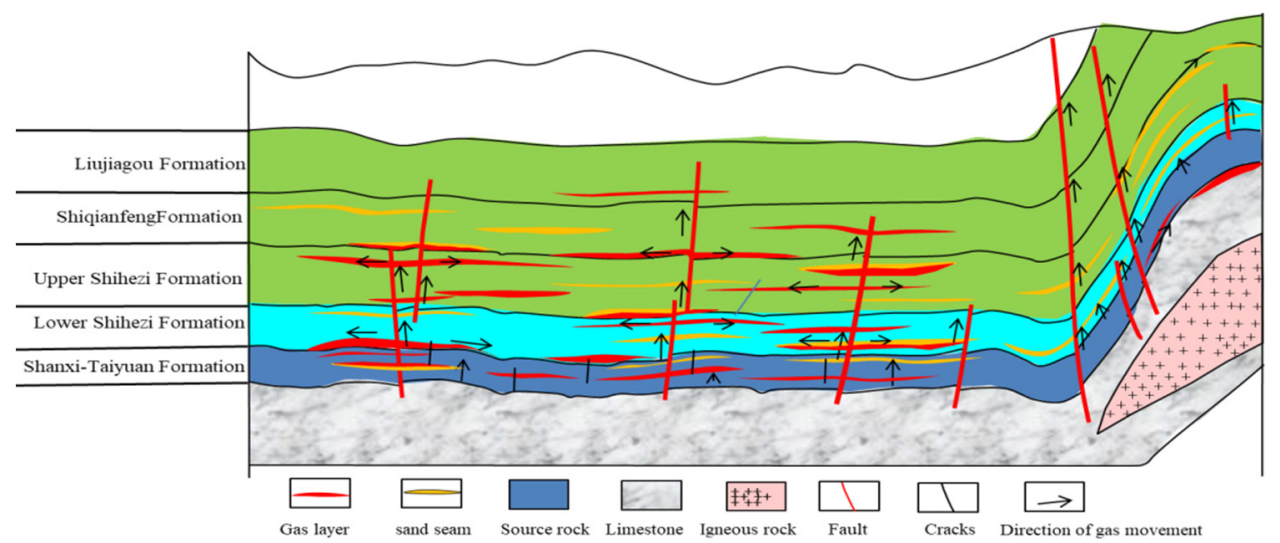

Fig.9. Gas Accumulation model map of tight sandstone in linxing area

\section{Conclusions}

(1) The tight sandstone gas in Linxing area has high methane content and low heavy hydrocarbon and nonhydrocarbon content; the drying coefficient is between 0.924 and 0.998 , which is mainly dry gas; the carbon isotope values generally show a positive carbon sequence change trend. In addition, the $\delta^{13} \mathrm{C}_{1}$ values are all less than $-30 \%$, which has the characteristics of typical organic gas; the $\mathrm{C}_{7}$ series of light hydrocarbons show the advantage of methylcyclohexane, and the $\mathrm{C}_{5-7}$ series mainly show the advantage of isoparaffins.

(2) The $\delta 13 \mathrm{C} 2$ values of tight sandstone gas in Linxing area are mostly greater than $-28 \%$; the methylcyclohexane index is greater than $50 \%$, the relative content of n-heptane is less than $35 \%$, and the relative content of C5-7 n-alkanes is mostly the same. Less than $30 \%$, mainly coal-derived gas, containing a small amount of mixed gas of coal-derived gas and oil-based gas.

(3) Tight sandstone gas in Linxing area is mainly in the mature stage. P1t natural gas changes with maturity, mainly from P1t's own source rock. P2h natural gas has obvious characteristics of diffusion and migration, except for P1t source rock. Mainly from P1s source rock.

(4) Tight sandstone gas in Linxing area is divided into three accumulation modes: remote source type, lower generation and upper storage type (upper Shihezi Formation-Shiqianfeng Formation sandbody accumulation away from the source rock); near source type lower generation and upper storage type Reservoir type (Accumulation of sand bodies in the Lower Shihezi Formation outside the source rock); In-source selfgeneration and self-storage type (Accumulation of sand bodies in the source rock of Shanxi Formation-Taiyuan Formation).

\section{references}

1. J.X. Dai, Y.Y. Ni, X.Q. Wu . PET EXPLORATION DEV.39( 2012).

2. P. Liu, W.F. Wang, L. Meng. J Jilin U:EARTH SCI ED. 46 (2016).

3. H.P. Yao, L. Li, X.G. Zhou. COAL SCI TECHNO.45 $(, 2017)$. 
4. J.S. Liang, X.S. Zhu, Y.H. Liu. J CHINA SOC. 41 (2016).

5. X.P. Liu, H.T. Zhao, X.X. Yan. NGGS.30(2019).

6. L.Zhao, X.Y.Xia, J.X. Dai. EXP PETROLEUM GEO.22( 2000)

7. W.Q. Hu, J.Z. Zhao, J. Li. NGGS.26(2015).

8. J.L. Yao, X.Y. Hu, L.Y. Fan. NGGS. 29 (2018) .

9. C.H. Ni, G.X. Liu, J.H. Zhu. PET GEO EXP.40(2018).

10. X.Q. Li, S.B. Feng, J.Li . ACTA PETROL SIN.28(2012).

11. S.M. Hao, L. Li, W. Zhang. OIL GAS GEO. 37( 2016).

12. N. Fu, S.C. Yang, Q. He. ACTA PETROL SIN,. 37 (2016).

13. Y.G. Xie, S.Z. Meng, H. Wan. COAL SCI TECHNO, 43(2015).

14. Y. Ge, G.H. Zhu, H. Wan . NGGS. 29(2018).

15. Y. Li, X.X. Ni, Y.B. Wang. NGGS.30(2019).

16. Y.G. Xie, S.Z. Meng, L.J. Gao. COAL SCI TECHNO.43(2015).

17. Y.L. Shen, Y. Qin, J. Shen. NAT GAS IND,.37 (2017).

18. J.Y. Gu, B. Zhang, M.Q. Guo..J CHINA COAL SOC. 41(2016).

19. J.X. Dai. NGGS, 1993, 4(1993).

20. X.Q. Wu, Q.Y. Liu, J.H. Zhu. MAR PET GEOLOGY. 79(2017).

21. W.X. Han, W.J. Ma, L.H. Hou . OIL GAS GEO.38 (2017).

22. J.X. Dai. PET EXPLORATION DEV.20( 1993).

23. W. Wang, Z.M. Shen, S.Q. Pei. EXP PET GEOLOGY. 40 (2018).

24. G.Y. Hu, J. Li, J. Li. SCI CHINA( SERIES D) . 37( 2007).

25. W.Q. Hu, Y.Y. Liu, Y.B. Li. J YANGTZE U:NAT SCI ED . 15(2018).

26. A. Prinzhofer , A.Y. Huc. CHE GEOLOGY. 126(1995).

27. A .A .Prinzhofer, E .Pernaton.. CHE GEOLOGY. 142(1997). 